\title{
Soil carbon dynamics in high-elevation temperate forests of Oaxaca (Mexico): thinning and rainfall effects
}

\author{
Dinámica del carbono del suelo en bosques templados de elevación alta en Oaxaca (México): \\ efectos del raleo y las lluvias
}

\author{
Vinisa Saynes ${ }^{\text {a,b }}$, Jorge D Etchevers ${ }^{\text {b }}$, Leopoldo Galicia ${ }^{c}$, Claudia Hidalgo b ${ }^{\text {, Julio Campo }}{ }^{\text {a* }}$ \\ a Universidad Nacional Autónoma de México, Instituto de Ecología, México D.F., México.

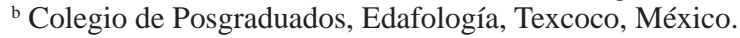 \\ *Corresponding autor: ' Universidad Nacional Autónoma de México, Instituto de Geografía e Instituto de Ecología, \\ A.P. 70-275, 04510 Mexico, D.F., Mexico, tel.: 52-55-56229027, jcampo@ecologia.unam.mx
}

\begin{abstract}
SUMMARY
To explore the forest harvest effects on biologically active fractions of soil organic matter dynamics, we evaluated soil total carbon (C-total) and soil microbial biomass carbon (SMBC) concentrations, and basal soil respiration (BSR) in old-growth forest (as control) and logged stands (logged one- and 20-yrs ago) in two regions (dry and wet regions) in temperate forests of Oaxaca, Mexico. Mean C-total values were higher in the Dry region than in the Wet region. Greater mean annual precipitation resulted in consistently lower BSR, but had inconsistent effects on the SMBC in dependence upon annual rainfall in the sampling year. In the dry region SMBC was higher in the dry season than in the rainy season, and BSR was higher in soils collected in the rainy season than those collected in the dry season. Forest logging consistently decreased C-total and SMBC concentrations and BSR. In contrast, rainfall seasonality in the Wet region did not affect SMBC concentration or BSR. On the other hand, in this region, the main response to the forest thinning application was an increase in the concentration of C-total. Overall, we conclude that the soil carbon pools and the effects of forest thinning on the biologically active fractions of soil organic matter will vary, depending on the details of the site's annual rainfall amount.
\end{abstract}

Key words: basal soil respiration, labile soil organic matter, microbial biomass, sustainable forest management.

\section{RESUMEN}

Las concentraciones de carbono (C) total y en la biomasa microbiana del suelo (CBMS), y la respiración basal del suelo (RBS) en bosques templados naturales (testigo) y rodales con aprovechamiento (después de uno y 20 años de la extracción), fueron determinadas en dos regiones (seca y húmeda) con bosques templados en Oaxaca, México, con el fin de explorar efectos del manejo en la dinámica de las fracciones biológicamente activas de la materia orgánica del suelo. Los valores medios de C-total fueron mayores en la región seca que en la húmeda. La mayor cantidad de precipitación media anual produjo menor RBS, pero tuvo efectos inconsistentes en la concentración de CBMS dependiendo de la cantidad de lluvia en el año de muestreo. En la región seca, el CBMS fue mayor en la estación seca que en la de lluvias y la RBS mayor en los suelos recolectados en la estación de lluvias que en aquellos recolectados en la seca. El aprovechamiento disminuyó las concentraciones de C-total y de CBMS, y la RBS. En la región húmeda, la estacionalidad en las lluvias no afectó la concentración de CBMS ni la RBS. En esta región, la principal respuesta al raleo del bosque fue el aumento en la concentración de C-total. Se concluye que los almacenes de carbono en el suelo y los efectos del raleo del bosque en las fracciones activas de la materia orgánica del suelo variarán dependiendo de los detalles en la cantidad de lluvia que recibe el sitio anualmente.

Palabras clave: biomasa microbiana, manejo forestal sostenible, materia orgánica lábil, respiración basal del suelo.

\section{INTRODUCTION}

Global forests are more widely distributed and cover a larger area $\left(4.17 \times 10^{9}\right.$ ha; i.e., $~ 30 \%$ of the world land area) than does any other single non-desert vegetation type (Huston and Wolverton 2009). One-third of these forests is primarily used for production of wood products. Approximately, $80 \%$ of the forests in the world are publicly owned
(FAO 2010) and have the potential to be managed by local communities. Community-based management systems of forests, if adequately designed and implemented, can be models of sustainable forest management and local empowerment (Bray et al. 2007). Sustainable forest management aims to ensure that the goods and services derived from forests meet present-day needs, and at the same time guarantee their ongoing availability and contribution to 
long-term development. The sustainable management of forest resources generates social and economic benefits, avoiding deforestation and restoring forest cover. Thus, currently, global wood harvest is $~ 3.4$ billion cubic meter per year, generating economic benefits around US $\$ 468$ billion (1.0\% of the global gross domestic product; FAO 2010).

In Mexico, pine and oak forests occupy 32 million ha, which represents $16.5 \%$ of the country area (Challenger and Soberón 2008). These forest areas are the richest ecosystems in Mexico with some 7,000 plant species (Rzedowski 1991), of which about 150 species are pines (Pinus spp.) and 170 oaks (Quercus spp.). These represent over $50 \%$ of all known pine and oak species (CONABIO 2000). Some species in these temperate forests produce timber of high commercial value in the forestry market. In the country, authorized annual wood removals reach $~ 56$ million cubic meters, and the annual contribution of the forestry sector is US $\$ 7$ billions ( $0.9 \%$ of the national gross domestic product), and $\sim 300,000$ employments (TorresRojo 2004). On the other hand, in Mexico, community forest projects under management by 8,500 ejidos comprise promising options for providing both carbon mitigation and sustainable rural development (Bray et al. 2007); for example some ejidos are engaged in wood processing and some have obtained certification from the Forest Stewardship Council or Smart Wood.

Sustainable forest management is evidently a goal worth pursuing in current times; however, our knowledge of its effects on environment is still limited. In order to preserve environmental services, it is essential to assess and monitor the impacts of wood extraction on ecosystem functions. Sustainable forest management includes selective tree extraction and thinning of natural forest. Forest thinning partially removes trees (20-35 \% of total stems) from a stand, reduces competition and wildfire risk, and improves tree productivity (Smith et al. 1997). The impacts of the so-called sustainable forest management on soil carbon stocks remain unclear. Although carbon (C) loss has been documented at clear-cut sites (Toland and Zak 1994, Striegl and Wickland 2001), further study is required to learn what happens in thinned sites. Scott et al. (2004) reported that harvesting $30 \%$ of aboveground biomass did not cause major soil carbon loss. Johnson et al. (2002) found short-term changes in soil carbon, even though effects of harvest treatment were not long lasting. Other authors have reported that soil total carbon was lower in second-growth stands because of lower tree, forest floor, and woody debris carbon stocks (Fredeen et al. 2005). Thus, despite the fact that temperate forests have a substantial role in the global carbon cycle (Huston and Wolverton 2009) and specific trends (Le Quéré et al. 2009), the existing information on the management effects on forests ecosystems carbon stocks strongly suggests that much remains unknown and there is a great deal to be done (Siry et al. 2005, Bond-Lamberty and Thomson 2010).
Since soil total carbon tends to respond slowly to management changes, measuring biologically active fractions of soil organic matter, such as soil microbial biomass carbon and basal soil respiration, has been proposed and thus they have become appropriate indicators. They respond rapidly to changes induced by forest management activities (Li et al. 2004, Sullivan et al. 2008).

Our objective was to assess the effects of forest management on soil total carbon, soil microbial biomass carbon and basal soil respiration in two regions of Oaxaca, Mexico, with gross climatic differences in annual rainfall amount. We collected soil samples from old-growth forests and selectively logged (thinned) stands within each region in dry and rainy seasons during two years to broaden our scope and explore the effects of seasonal changes.

\section{METHODS}

Study sites. This study was conducted at Ixtlán de Juárez (North Oaxaca Mountain System in the state of Oaxaca in Mexico). The region is characterized by rugged topography with medium to steep slopes (30 to $60 \%$ ). The soil parent material is derived from igneous rocks (table 1). Soils show a subsurface accumulation of low activity clays (and low base saturation), and are classified in the FAO system as Humic Acrisol. Clay contents are $8 \%$ in the dry region and $42 \%$ in the wet region; silt and sand contents are 5 and $8 \%$ (in dry and wet regions, respectively) and 95 and $52 \%$ (in dry and wet regions, respectively). The natural vegetation of the region is high-altitude temperate forest (2,200 to $2,800 \mathrm{~m}$ a.s.l.).

Approach: old growth vs. thinned forest under different annual rainfall amounts. Ixtlán de Juárez region shows a complex physiography that allows a great diversity of interconnected environments. Pine-oak forests of the region show climatic differences dependent on their location. Long-term climatic data from weather stations show that the region is characterized by a distinct period of low precipitation. The rainfall pattern is strongly seasonal with seven dry months (November to May). The region facing the Pacific Ocean receives $30 \%$ less annual precipitation (807 $\pm 67 \mathrm{~mm}$; mean $\pm \mathrm{SE}$ ) (dry region), compared to its more humid counterpart, facing the Gulf of Mexico (1221 $\pm 86 \mathrm{~mm}$ ) (wet region) (years 1955 to 2006) (Servicio Meteorológico Nacional, Mexico, personal communication). Mean annual temperatures are 17.1 and $17.9^{\circ} \mathrm{C}$ in dry and wet regions, respectively.

The extreme annual rainfall values recorded in the study years, 2004 and 2006, were 1,242 and $991 \mathrm{~mm}$, respectively, in the wet region, and 818 and $657 \mathrm{~mm}$, respectively, in the dry region.

The study sites were chosen as representatives of forest use by stakeholders of Ixtlán de Juárez in the two climate regions (dry region: $17^{\circ} 23^{\prime} 54^{\prime \prime} \mathrm{N}, 96^{\circ} 29^{\prime} 32^{\prime}$ ' $\mathrm{W}$, and wet region: $17^{\circ} 23^{\prime} 37^{\prime \prime}$ N, $96^{\circ} 28^{\prime} 41^{\prime \prime} \mathrm{W}$ ), distributed over an 
Table 1. Site characteristics (mean \pm standard error; $n=5$ ) for different high-elevation temperate forests of Ixtlán de Juárez, Mexico. Características de los sitios (media \pm error estándar) de los diferentes bosques templados de elevación alta en Ixtlán de Juárez, México.

\begin{tabular}{|c|c|c|c|c|c|c|}
\hline \multirow{2}{*}{$\begin{array}{l}\text { Characteristic } \\
\begin{array}{l}\text { Time forest recovery } \\
\text { since management }\end{array}\end{array}$} & \multicolumn{3}{|c|}{$\begin{array}{c}\text { Dry region } \\
\text { (mean annual precipitation } 807 \text { mm) }\end{array}$} & \multicolumn{3}{|c|}{$\begin{array}{c}\text { Wet region } \\
\text { (mean annual precipitation 1,221 mm) }\end{array}$} \\
\hline & $\begin{array}{c}\text { Logged forest } \\
1 \text { year-ago } \\
(\mathrm{FL}-1)\end{array}$ & $\begin{array}{l}\text { Logged forest } \\
20 \text { years-ago } \\
\text { (FL-20) }\end{array}$ & $\begin{array}{l}\text { Old growth } \\
\text { forest }\end{array}$ & $\begin{array}{c}\text { Logged forest } \\
1 \text { year-ago } \\
(\mathrm{FL}-1)\end{array}$ & $\begin{array}{c}\text { Logged forest } \\
20 \text { years-ago } \\
(\text { FL-20) }\end{array}$ & $\begin{array}{l}\text { Old growth } \\
\text { forest }\end{array}$ \\
\hline \multicolumn{7}{|l|}{ Vegetation $^{1}$} \\
\hline Basal area $\left(\mathrm{m}^{2} \mathrm{ha}^{-1}\right)$ & $4.6 \pm 0.3$ & $4.5 \pm 0.6$ & $19.0 \pm 1.8$ & $5.7 \pm 0.8$ & $4.7 \pm 0.4$ & $15.0 \pm 1.4$ \\
\hline Tree height (m) & $14.4 \pm 0.9$ & $7.3 \pm 0.2$ & $11.3 \pm 0.5$ & $8.5 \pm 0.4$ & $9.6 \pm 0.2$ & $9.7 \pm 0.4$ \\
\hline \multicolumn{7}{|l|}{ Forest floor } \\
\hline $\begin{array}{l}\text { Coarse wood litter } \\
\left(\text { dry mass: } \mathrm{Mg} \mathrm{ha}^{-1} \text { ) }\right.\end{array}$ & $86.5 \pm 0.02$ & $32.9 \pm 0.05$ & $24.7 \pm 0.02$ & $87.5 \pm 0.07$ & $60.2 \pm 0.09$ & $83.2 \pm 0.1$ \\
\hline Litter C ( Mg hä) & $20.2 \pm 0.4$ & $24.8 \pm 0.5$ & $24.8 \pm 1.4$ & $32.6 \pm 2.1$ & $26.8 \pm 0.6$ & $27.4 \pm 1.4$ \\
\hline \multicolumn{7}{|l|}{ Soil $^{2}$} \\
\hline Bulk density $\left(\mathrm{Mg} \mathrm{m}^{-3}\right)$ & $0.8 \pm 0.002$ & $0.5 \pm 0.001$ & $0.5 \pm 0.001$ & $0.4 \pm 0.001$ & $0.7 \pm 0.002$ & $0.6 \pm 0.001$ \\
\hline $\mathrm{pH}$ & $5.2 \pm 0.08$ & $4.5 \pm 0.02$ & $4.3 \pm 0.05$ & $4.2 \pm 0.03$ & $4.1 \pm 0.03$ & $4.1 \pm 0.07$ \\
\hline Total N ( $\left.\mathrm{g} \mathrm{kg}^{-1}\right)$ & $4.1 \pm 2.2$ & $7.3 \pm 0.9$ & $7.8 \pm 1.4$ & $8.9 \pm 1.6$ & $6.7 \pm 1.6$ & $7.0 \pm 2.1$ \\
\hline
\end{tabular}

${ }^{1}$ For all trees at least $2.5 \mathrm{~cm}$ in diameter at the start of the study. ${ }^{2}$ For upper $0-5 \mathrm{~cm}$ soil depth.

area of $119.2 \mathrm{~km}^{2}$. Inside each region (i.e., dry and wet regions) old-growth forest (old-growth forest; without tree removal), forest logged one year ago (FL-1; thinned in the year 2002) and forest logged 20 years ago (FL-20; thinned in the year 1983) were selected (table 1). The dominant tree species in the dry region were Pinus oaxacana Mirov., P. patula Schlecht et Cham. and P. douglasiana Martínez; and in the wet region were P. pseudostrobus Lindl., $P$. rudis Endl., $P$. oaxacana and $P$. ayacahuite Ehren.

Forest management: a sustainable thinning strategy. Ixtlán de Juárez is considered an example of communitybased forest management for commercial production in Mexico (Chapela 2007). It is one of the 43 Mexican communities with certified wood production ${ }^{1}$. Total certified forest area spans 15,749 ha, and $~ 42 \%$ of this area is under timber production, the remaining $58 \%$ of the total forest area is under regeneration stage. The communitybased forest management enterprise in this community generates 250 temporary and permanent jobs. Ixtlán de Juárez production system includes the extraction of timber products from the forest. The forest management applied is an intermediate logging system. This production system focuses on young trees removal (before trees reach a commercial size) to re-distribute tree increments and reduce tree competition for light and nutrients. The logging rotation period is around 20 years. At the end of each rotation a new forest management program is elaborated. Forest management plan fulfills sustainability requirements established by Smartwood. However, one of the remarks to the plan was to include an analysis of environmental impacts

\footnotetext{
${ }^{1}$ www.smartwood.org, July 2006.
}

on the resources affected by wood extraction, particularly on the soil.

This study was focused on forest stands that have been used exclusively for timber extraction by partial tree removal (30\% of the total tree stems) from the site, with the exception of the old-growth forest.

Soil sampling. To determine the soil total carbon (C-total) and microbial biomass carbon (SMBC) concentrations, and basal soil respiration (BSR), soils of each forest and of each climatic region were sampled during the dry season (April) and halfway through the rainy season (September) of 2004 and 2006. In each type of forest (i.e., old-growth, logged one year ago, and logged 20 years ago) of each climatic region, five soil cores of the upper $0.05 \mathrm{~m}$ profile were collected systematically from the middle line of each of the five 0.1 ha $(20 \mathrm{~m} \times 50 \mathrm{~m})$ plots (evenly distributed over a 1.5 ha area). Soil samples were combined in each plot, namely, five composite samples at each site, and stored at $4{ }^{\circ} \mathrm{C}$ for up to one week until processing.

Laboratory analyses. In the laboratory, composite soil samples were hand homogenized and sieved (to pass a $2 \mathrm{~mm}$ mesh) and a sub-sample dried at constant weight for moisture determination. The remaining soil was used to determine soil total carbon and soil microbial biomass carbon concentrations, and measure basal soil respiration.

Soil total carbon concentration was analyzed in an automated carbon-analyzer (Shimadzu 5005 A), after manually removing visible roots and gridding a $5 \mathrm{~g}$ air-dried subsample to be passed through a 100 mesh screen. Soil microbial biomass carbon concentration was determined by using the chloroform-fumigation-extraction method 
(Vance et al. 1987), using replicated samples of fresh soil. Fumigated and non-fumigated samples were incubated for $24 \mathrm{~h}$ at $24{ }^{\circ} \mathrm{C}$ (soil moisture was standardized before soil incubation, in both fumigated and non-fumigated samples). Microbial biomass carbon was extracted from both fumigated and non-fumigated samples with $0.5 \mathrm{M} \mathrm{K}_{2} \mathrm{SO}_{4}$, filtered through a Whatman No. 42 paper and the concentration of carbon measured by using an automated carbonanalyzer (Shimadzu 5005 A). Concentrations of carbon in the non-fumigated extracts were subtracted from the fumigated extract, and a conversion factor $k_{\mathrm{C}}$ for microbial carbon equal to 0.45 (Vance et al. 1987) was used to estimate soil microbial biomass carbon.

Basal soil respiration was determined from 50 g subsamples of sieved (2 mm mesh) fresh soil. Duplicate soil subsamples were moistened to $50 \%$ water-filled pore space following light tamping in a PVC tube $(3.5 \mathrm{~cm}$ in diameter and $10 \mathrm{~cm}$ depth) and incubated in $1 \mathrm{~L}$ glass jars in the dark at $25^{\circ} \mathrm{C}$. Glass jars contained flasks with $10 \mathrm{~mL}$ of $1.0 \mathrm{M} \mathrm{NaOH}$ to absorb $\mathrm{CO}_{2}$. The jars were normally closed but opened periodically to maintain aerobic conditions. Water loss in the jars was monitored by weight and replenished after opening. Alkali traps were replaced at 1 , 2, 3, 6, and 9 days, and after each week for 96 days. The carbon dioxide evolution was determined adding $10 \mathrm{~mL}$ of $1 \mathrm{M} \mathrm{BaCl}_{2}$ and titrating residual alkali $(\mathrm{NaOH})$ to $\mathrm{pH} 7$ with $1 \mathrm{M} \mathrm{HCl}$ (Anderson 1982). Basal soil respiration was calculated as the linear rate of carbon mineralization during 5 - 96 days to avoid most flush activity due to drying and rewetting.

Statistical analyses. Climate and thinning effects on concentrations of total carbon and soil microbial biomass carbon and on basal soil respiration were analyzed by repeated measurements ANOVA for each region separately (i.e., one model for each region). Two within-subject factors were selected: year (years 2004 and 2006) and season (rainy and dry seasons), while thinning was selected as the between-subject factor. A Greenhouse-Geisser adjustment was applied when data did not fulfill the circularity condition. Tukey tests were used to examine differences between means when the year and/or seasonal effects were significant $(P<0.05)$. The package Statistica 7.0 was used to perform all statistical analyses.

\section{RESULTS}

\section{Soil total carbon and soil microbial biomass.}

- Dry region. Soil total carbon concentrations were very consistent over time (i.e., along the study) (table 2). Forest thinning decreased total carbon concentrations in FL-1 relative to old-growth forest and FL-20 $(P<0.001)$. In contrast, soil microbial biomass carbon concentrations differed between sampling years and between sampling seasons. Soil microbial biomass carbon concentrations varied in both between sampling years and between seasons; they were higher during the drier year (2006) than in the wet one (2004) $(P=0.008)$, and reached their maximum during the dry season and the minimum during the wet season $(P=0.009)$. The effect of forest thinning significantly decreased soil microbial biomass carbon concentration in soils from FL-1 (by 33 \% relative to old-growth forest, $P=0.004$ ).

Soil microbial biomass amounted to $1.1 \pm 0.1 \%$ (mean \pm SE) of total carbon in the soil (table 3). Soil microbial biomass carbon: total carbon ratio varied between sampling years, with higher mean values in soils collected in the drier year (i.e., year 2006) than in soils collected in the wet year (year 2004) $(P=0.004)$. In contrast, soil microbial biomass carbon: total carbon values were significantly different between seasons. Across all forest classes, soil microbial biomass carbon: total carbon values were significantly higher in FL-1 relative to old-growth forest and FL-20, reflecting changes in total carbon concentrations $(P=0.002)$.

- Wet region. In all forests, total carbon concentrations did not change significantly over time (table 2). Forest thinning increased total carbon concentration in soils from FL-1 compared to soils of the other forests by $\sim 50 \%(P=0.029)$. Seasonal patterns in microbial biomass carbon concentrations varied as a function of the sampling year (season*year-class effect, $P=0.014$ ), but not as a function of thinning time (season*thinningclass effect, $P=0.019$ ). In addition, the thinning of forest did not have a significant effect on soil microbial biomass carbon concentration in any of the different forest types.

Soil microbial biomass carbon: total carbon ratios in the wet region ranged from 0.4 to $1.6 \%(1.1 \pm 0.2 \%)$ (table 3 ). This ratio did not vary significantly during the sampling year, though it tended to increase in the year 2006 relative to year 2004. Although, soil microbial biomass carbon: total carbon ratios tend to decline during the wet season; this seasonal pattern varied as a function of sampling year (year*season effect, $P=0.001$ ). We found a decreasing gradient in soil microbial biomass carbon: total carbon ratio in the direction old-growth forest $>$ FL-20 $>$ FL- 1 . The corresponding ANOVA indicated that this gradient is highly significant $(P<0.001)$, and paired comparisons using the Tukey-Kramer HSD test showed that soils of the old-growth forest and FL-20 consistently sustained greater soil microbial biomass carbon: total carbon ratios; while soils from FL-1 were the most heavily damaged by thinning.

\section{Basal soil respiration}

- Dry region. Overall basal soil respiration levels increased with decreasing precipitation (table 2). Basal soil respiration was higher in soil samples collected in 
Table 2. Soiltotal(C-total)andmicrobialbiomass carbon(SMBC)concentrations, andbasal soilrespiration(BSR)(mean \pm standarderror; $\mathrm{n}=5$ ) for different high-elevation temperate forest soils of Ixtlán de Juárez, Mexico.

Concentraciones de carbono total (C-total) y en la biomasa microbiana del suelo (CBMS), y respiración basal del suelo (RBS) (media \pm error estándar) de los diferentes bosques templados de elevación alta en Ixtlán de Juárez, México.

\begin{tabular}{|c|c|c|c|c|c|c|}
\hline \multirow[b]{2}{*}{ Year/Season/Parameter } & \multicolumn{3}{|c|}{$\begin{array}{c}\text { Dry region } \\
\text { (mean annual precipitation } 807 \mathrm{~mm} \text { ) }\end{array}$} & \multicolumn{3}{|c|}{$\begin{array}{c}\text { Wet region } \\
\text { (mean annual precipitation } 1,221 \mathrm{~mm} \text { ) }\end{array}$} \\
\hline & $\begin{array}{l}\text { Logged forest } \\
1 \text { year-ago } \\
\text { (FL-1) }\end{array}$ & $\begin{array}{l}\text { Logged forest } \\
20 \text { years-ago } \\
\text { (FL-20) }\end{array}$ & $\begin{array}{l}\text { Old growth } \\
\text { forest }\end{array}$ & $\begin{array}{c}\text { Logged forest } \\
1 \text { year-ago } \\
(\mathrm{FL}-1)\end{array}$ & $\begin{array}{l}\text { Logged forest } \\
20 \text { years-ago } \\
\text { (FL-20) }\end{array}$ & $\begin{array}{l}\text { Old growth } \\
\text { forest }\end{array}$ \\
\hline \multicolumn{7}{|l|}{ Year 2004} \\
\hline \multicolumn{7}{|l|}{ Dry season } \\
\hline C-total (mg g-1 soil) & $86.1 \pm 5.6$ & $154.6 \pm 9.8$ & $152.9 \pm 7.81$ & $186.0 \pm 14.3$ & $101.0 \pm 14.2$ & $126.1 \pm 12.5$ \\
\hline SMBC (mg g ${ }^{-1}$ soil) & $764 \pm 102$ & $1,779 \pm 433$ & $1,400 \pm 151$ & $1,732 \pm 336$ & $1,510 \pm 370$ & $2,029 \pm 532$ \\
\hline BSR (mg g-1 soil day $\left.{ }^{-1}\right)$ & $34.7 \pm 3.9$ & $30.3 \pm 4.2$ & $43.3 \pm 6.3$ & $44.4 \pm 2.5$ & $29.5 \pm 3.4$ & $34.3 \pm 3.8$ \\
\hline \multicolumn{7}{|l|}{ Rainy season } \\
\hline C-total (mg g ${ }^{-1}$ soil) & $86.5 \pm 8.1$ & $166.3 \pm 18.6$ & $215.7 \pm 20.8$ & $216.0 \pm 27.4$ & $143.2 \pm 9.3$ & $117.0 \pm 9.8$ \\
\hline SMBC (mg g-1 soil) & $1,026 \pm 31$ & $1135 \pm 371$ & $1,637 \pm 528$ & $1348 \pm 32$ & $1,226 \pm 70$ & $1525 \pm 90$ \\
\hline BSR (mg g ${ }^{-1}$ soil day ${ }^{-1}$ ) & $36.2 \pm 2.6$ & $15.5 \pm 1.4$ & $39.9 \pm 7.4$ & $31.4 \pm 0.4$ & $28.2 \pm 3.5$ & $32.0 \pm 5.0$ \\
\hline \multicolumn{7}{|l|}{ Year 2006} \\
\hline \multicolumn{7}{|l|}{ Dry season } \\
\hline C-total (mg g-1 soil) & $101.2 \pm 16.4$ & $154.3 \pm 5.9$ & $164.7 \pm 9.8$ & $193.5 \pm 21.7$ & $117.6 \pm 18.5$ & $166.6 \pm 12.5$ \\
\hline SMBC (mg g ${ }^{-1}$ soil) & $1,498 \pm 59$ & $2,177 \pm 131$ & $2,904 \pm 225$ & $2,467 \pm 235$ & $2,175 \pm 467$ & $2,610 \pm 254$ \\
\hline BSR (mg g ${ }^{-1}$ soil day ${ }^{-1}$ ) & $24.2 \pm 3.2$ & $17.9 \pm 3.2$ & $29.7 \pm 3.6$ & $32.6 \pm 4.4$ & $23.4 \pm 8.0$ & $25.5 \pm 2.8$ \\
\hline \multicolumn{7}{|l|}{ Rainy season } \\
\hline C-total (mg g-1 soil) & $83.5 \pm 8.8$ & $161.2 \pm 22.0$ & $224.7 \pm 19.7$ & $228.9 \pm 31.8$ & $156.7 \pm 10.1$ & $131.9 \pm 13.5$ \\
\hline SMBC (mg g ${ }^{-1}$ soil) & $1,657 \pm 116$ & $1,990 \pm 237$ & $1,386 \pm 121$ & $987 \pm 92$ & $925 \pm 50$ & $1,066 \pm 114$ \\
\hline BSR (mg g ${ }^{-1}$ soil day $\left.{ }^{-1}\right)$ & $30.5 \pm 2.2$ & $45.8 \pm 5.6$ & $71.6 \pm 8.9$ & $50.9 \pm 8.2$ & $49.6 \pm 5.2$ & $34.1 \pm 4.7$ \\
\hline \multicolumn{7}{|l|}{ Average } \\
\hline C-total (mg g-1 soil) & $89.8 \pm 4.6$ & $159.1 \pm 13.3$ & $189.5 \pm 19.9$ & $206.1 \pm 11.7$ & $129.6 \pm 9.4$ & $135.4 \pm 6.8$ \\
\hline SMBC (mg g-1 soil) & $1,236 \pm 139$ & $1,770 \pm 200$ & $1,832 \pm 96$ & $1,633 \pm 185$ & $1,459 \pm 191$ & $1,807 \pm 175$ \\
\hline BSR (mg g ${ }^{-1}$ soil day ${ }^{-1}$ ) & $31.4 \pm 2.2$ & $27.4 \pm 3.0$ & $46.1 \pm 2.2$ & $39.7 \pm 2.7$ & $32.7 \pm 2.7$ & $31.5 \pm 5.1$ \\
\hline
\end{tabular}

Data for upper 0-5 cm soil depth.

Table 3. Soil microbial biomass carbon: total carbon (SMBC: C-total) ratios (mean \pm standard error; $n=5$ ) for different highelevation temperate forest soils of Ixtlán de Juárez, Mexico.

Relación carbono en la biomasa microbiana del suelo: carbono total (CBMS: C-total) (media \pm error estándar) de los diferentes bosques templados de elevación alta en Ixtlán de Juárez, México.

\begin{tabular}{|c|c|c|c|c|c|c|}
\hline \multirow[b]{2}{*}{ Year/Season } & \multicolumn{3}{|c|}{$\begin{array}{c}\text { Dry region } \\
\text { (mean annual precipitation } 807 \mathrm{~mm} \text { ) }\end{array}$} & \multicolumn{3}{|c|}{$\begin{array}{c}\text { Wet region } \\
\text { (mean annual precipitation 1,221 mm) }\end{array}$} \\
\hline & $\begin{array}{l}\text { Logged forest } \\
1 \text { year-ago } \\
\text { (FL-1) }\end{array}$ & $\begin{array}{c}\text { Logged forest } \\
20 \text { years-ago } \\
\text { (FL-20) }\end{array}$ & $\begin{array}{l}\text { Old growth } \\
\text { forest }\end{array}$ & $\begin{array}{l}\text { Logged forest } \\
1 \text { year-ago } \\
\text { (FL-1) }\end{array}$ & $\begin{array}{c}\text { Logged forest } \\
20 \text { years-ago } \\
\text { (FL-20) }\end{array}$ & $\begin{array}{l}\text { Old growth } \\
\text { forest }\end{array}$ \\
\hline \multicolumn{7}{|l|}{ Year 2004} \\
\hline \multicolumn{7}{|l|}{ Dry season } \\
\hline SMBC: C-total (\%) & $0.89 \pm 0.48$ & $1.15 \pm 0.19$ & $0.92 \pm 0.06$ & $0.93 \pm 0.08$ & $1.49 \pm 0.13$ & $1.61 \pm 0.15$ \\
\hline \multicolumn{7}{|l|}{ Rainy season } \\
\hline SMBC: C-total (\%) & $1.19 \pm 0.34$ & $0.68 \pm 0.11$ & $0.76 \pm 0.24$ & $0.62 \pm 0.06$ & $0.86 \pm 0.04$ & $1.30 \pm 0.15$ \\
\hline \multicolumn{7}{|l|}{ Year 2006} \\
\hline \multicolumn{7}{|l|}{ Dry season } \\
\hline SMBC: C-total (\%) & $1.48 \pm 0.23$ & $1.41 \pm 0.07$ & $1.76 \pm 0.07$ & $1.27 \pm 0.02$ & $1.85 \pm 0.12$ & $1.57 \pm 0.10$ \\
\hline \multicolumn{7}{|l|}{ Rainy season } \\
\hline SMBC: C-total (\%) & $1.98 \pm 1.23$ & $1.23 \pm 0.16$ & $0.67 \pm 0.04$ & $0.43 \pm 0.04$ & $0.59 \pm 0.05$ & $0.81 \pm 0.14$ \\
\hline Average & $1.38 \pm 0.27$ & $1.12 \pm 0.09$ & $1.01 \pm 0.12$ & $0.81 \pm 0.10$ & $1.20 \pm 0.10$ & $1.32 \pm 0.10$ \\
\hline
\end{tabular}

Data for upper 0-5 cm soil depth. 
2006 than in those collected in $2004(P=0.02)$, and in dry season than in wet season soils $(P=0.003)$. Forest thinning consistently decreased basal soil respiration levels in logging forests (i.e., FL-1 and FL-20) relative to old-growth forest $(P<0.007)$.

The basal soil respiration:total carbon ratios did not vary between years, nor between seasons (table 4); a year by season interaction $(P<0.001)$ showed that values of this ratio in samples collected in 2006 were almost double in the wet season than in the dry season. Basal soil respiration: total carbon ratio changed significantly across forests $(P<0.001)$. This ratio reached its minimum in FL-20 and was at its highest level in FL-1. Soils from the old-growth forest constituted an intermediate statistical group.
Also, basal soil respiration: soil microbial biomass carbon ratios were very consistent across sampling times (table 4). In this region, the thinning of forest decreased basal soil respiration: soil microbial biomass carbon ratios as occurred with the basal soil respiration:total carbon ratio in soils from FL-20 relative to old-growth forest and FL-1 $(P=0.047)$.

- Wet region. The variation in basal soil respiration over the sampling time detected in soils of the dry region was not observed in the wet region (table 2). In the case of the wet region, we detected a year by season interaction in the levels of basal soil respiration $(P<0.001)$. However, there is a significant thinning-related difference in basal soil respiration; this flux increased its

Table 4. Basal soil respiration: total carbon (BSR: C-total) and basal soil respiration: soil microbial biomass carbon (BSR: SMBC) ratios (mean \pm standard error; $\mathrm{n}=5$ ) for different high-elevation temperate forest soils of Ixtlán de Juárez, Mexico.

Relaciones respiración basal del suelo: carbono total (RBS: C-total) y respiración basal del suelo: carbono en la biomasa microbiana de suelo (RBS: CBMS) (media \pm error estándar) de los diferentes bosques templados de elevación alta en Ixtlán de Juárez, México.

\begin{tabular}{|c|c|c|c|c|c|c|}
\hline \multirow[b]{2}{*}{ Year/Season/Parameter } & \multicolumn{3}{|c|}{$\begin{array}{c}\text { Dry region (dry) } \\
\text { (mean annual precipitation } 807 \mathrm{~mm} \text { ) }\end{array}$} & \multicolumn{3}{|c|}{$\begin{array}{c}\text { Wet region (wet) } \\
\text { (mean annual precipitation } 1,221 \mathrm{~mm} \text { ) }\end{array}$} \\
\hline & $\begin{array}{c}\text { Logged forest } \\
1 \text { year-ago } \\
\text { (FL-1) }\end{array}$ & $\begin{array}{c}\text { Logged forest } \\
20 \text { years-ago } \\
\text { (FL-20) }\end{array}$ & $\begin{array}{l}\text { Old growth } \\
\text { forest }\end{array}$ & $\begin{array}{c}\text { Logged forest } \\
1 \text { year-ago } \\
\text { (FL-1) }\end{array}$ & $\begin{array}{l}\text { Logged forest } \\
20 \text { years-ago } \\
\text { (FL-20) }\end{array}$ & $\begin{array}{l}\text { Old growth } \\
\text { forest }\end{array}$ \\
\hline \multicolumn{7}{|l|}{ Year 2004} \\
\hline \multicolumn{7}{|l|}{ Dry season } \\
\hline $\begin{array}{l}\text { BSR:C-total } \\
\text { (mg C day } \text { g C }^{-1} \text { ) }\end{array}$ & $403 \pm 65$ & $196 \pm 16$ & $282 \pm 40$ & $238 \pm 13$ & $291 \pm 26$ & $272 \pm 12$ \\
\hline $\begin{array}{l}\text { BSR:SMBC } \\
\left(\mathrm{mg} \mathrm{C} \mathrm{day}^{-1} \mathrm{mg} \mathrm{C}^{-1}\right)\end{array}$ & $45.4 \pm 11.0$ & $17.0 \pm 5.5$ & $30.9 \pm 2.9$ & $25.4 \pm 2.3$ & $19.5 \pm 1.6$ & $16.9 \pm 2.5$ \\
\hline \multicolumn{7}{|l|}{ Rainy season } \\
\hline $\begin{array}{l}\text { BSR:C-total } \\
\left(\mathrm{mg} \mathrm{C} \text { day }^{-1} \mathrm{~g} \mathrm{C}^{-1}\right)\end{array}$ & $418 \pm 59$ & $93 \pm 11$ & $185 \pm 54$ & $145 \pm 13$ & $196 \pm 30$ & $273 \pm 40$ \\
\hline $\begin{array}{l}\text { BSR:SMBC } \\
\left(\mathrm{mg} \mathrm{C} \text { day }^{-1} \mathrm{mg} \mathrm{C}^{-1}\right)\end{array}$ & $35.3 \pm 2.4$ & $13.7 \pm 2.7$ & $24.3 \pm 5.2$ & $23.2 \pm 0.5$ & $22.9 \pm 2.5$ & $20.9 \pm 2.4$ \\
\hline \multicolumn{7}{|l|}{ Year 2006} \\
\hline \multicolumn{7}{|l|}{ Dry season } \\
\hline $\begin{array}{l}\text { BSR:C-total } \\
\left(\mathrm{mg} \mathrm{C} \text { day }^{-1} \mathrm{~g} \mathrm{C}^{-1}\right)\end{array}$ & $239 \pm 27$ & $116 \pm 19$ & $180 \pm 4$ & $168 \pm 8$ & $198 \pm 10$ & $152 \pm 17$ \\
\hline $\begin{array}{l}\text { BSR:SMBC } \\
\left(\mathrm{mg} \mathrm{C} \mathrm{day}^{-1} \mathrm{mg} \mathrm{C}^{-1}\right)\end{array}$ & $16.1 \pm 1.0$ & $8.2 \pm 1.2$ & $10.2 \pm 0.2$ & $13.2 \pm 1.6$ & $10.7 \pm 0.5$ & $9.7 \pm 0.3$ \\
\hline \multicolumn{7}{|l|}{ Rainy season } \\
\hline $\begin{array}{l}\text { BSR:C-total } \\
\left(\mathrm{mg} \mathrm{C} \text { day }^{-1} \mathrm{~g} \mathrm{C}^{-1}\right)\end{array}$ & $365 \pm 54$ & $284 \pm 66$ & $318 \pm 35$ & $222 \pm 14$ & $316 \pm 62$ & $258 \pm 31$ \\
\hline $\begin{array}{l}\text { BSR:SMBC } \\
\left(\mathrm{mg} \mathrm{C} \text { day }^{-1} \mathrm{mg} \mathrm{C}^{-1}\right)\end{array}$ & $18.4 \pm 4.6$ & $23.0 \pm 8.4$ & $51.6 \pm 4.7$ & $51.5 \pm 8.4$ & $53.5 \pm 9.4$ & $32.0 \pm 5.1$ \\
\hline \multicolumn{7}{|l|}{ Average } \\
\hline $\begin{array}{l}\text { BSR:C-total } \\
\left(\mathrm{mg} \mathrm{C} \text { day }^{-1} \mathrm{~g} \mathrm{C}^{-1}\right)\end{array}$ & $356 \pm 47$ & $172 \pm 22$ & $242 \pm 23$ & $193 \pm 9$ & $251 \pm 21$ & $239 \pm 17$ \\
\hline $\begin{array}{l}\text { BSR:SMBC } \\
\left(\mathrm{mg} \mathrm{C} \mathrm{day}^{-1} \mathrm{mg} \mathrm{C}^{-1}\right)\end{array}$ & $28.8 \pm 5.1$ & $15.5 \pm 3.0$ & $29.3 \pm 4.8$ & $28.4 \pm 4.9$ & $26.7 \pm 3.5$ & $19.9 \pm 2.1$ \\
\hline
\end{tabular}

Data for upper 0-5 cm soil depth. 
levels in FL-1 relative to old-growth forest $(P=0.003)$.

Inter-annual variation in basal soil respiration: total carbon ratio was a function of the sampling season (year*season interaction, $P=0.027$ ) (table 4). The significant inter-annual variation seems to be caused by erratic variation in thinning forests. In contrast, rainfall seasonality and thinning of forests did not affect the basal soil respiration: total carbon ratio.

As in the case of the dry region, in the wet region basal soil respiration: soil microbial biomass carbon ratio did not change between sampling years (table 4). The basal soil respiration: soil microbial biomass carbon ratio varied throughout seasons, but the seasonal pattern varied as a function of the sampling year (seasonal*year effect, $P=0.002$ ). There were no significant differences in basal soil respiration: soil microbial biomass carbon ratio among forests.

\section{DISCUSSION}

Regional trends in soil carbon. In our study sites, there is a strong association between soil carbon concentration and precipitation at a regional scale. Soil total carbon concentration and basal soil respiration in the old-growth forest is higher in the dry region, compared to the wet region (by $40 \%$ in the case of total carbon, and by $46 \%$ in the case of basal soil respiration) (table 2). Changes in basal soil respiration levels may reflect a change in the amount of carbon in the soils themselves, considering that soil microbial biomass carbon in old-growth forest did not vary between regions, and soil microbial biomass carbon accounted for greater levels of total carbon in soils with high precipitation (i.e., old-growth forest from the wet region) than in soils with lower precipitation (i.e., old-growth forest from the dry region), by 30\% (table 3). When considering the results of soil microbial biomass carbon concentrations in both regions over the years, we observed that soils receiving low rainfall (i.e., from the dry region) showed responses to variation in the annual precipitation between years, contrasted with those recording high rainfall (i.e., from the wet region). Thus, although the distance between the study areas is less than $20 \mathrm{~km}$, the 800 to $1,200 \mathrm{~mm}$ per year gradient in total annual precipitation appears to be an important driving force of soil carbon status and dynamics in Ixtlán de Juárez, Oaxaca.

Total carbon concentrations in soils of the study sites are comparable to lower levels reported for other temperate forests (14 - $400 \mathrm{mg} \mathrm{g}^{-1}$ soil; Finer et al. 2003, Fredeen et al. 2005). Microbial biomass carbon concentrations in our study sites are higher than those reported for temperate forest soils in Spain and USA (300 - 1,200 $\mathrm{mg} \mathrm{g}^{-1}$; Franzluebber et al. 2001, Li et al. 2004, Sullivan et al. 2008), but are in the lower bound of the range reported by Schilling et al. (1999) (1600 to $2500 \mathrm{mg} \mathrm{g}^{-1}$ ). Also, the overall levels of basal soil respiration we observed in these soils $\left(\mathrm{C}-\mathrm{CO}_{2}: 10-100 \mu \mathrm{g} \mathrm{g}^{-1}\right.$ soil day ${ }^{-1}$ ) are in the lower half of the range reported for temperate forest soils $\left(\mathrm{C}-\mathrm{CO}_{2}\right.$ : $10-200 \mu \mathrm{g} \mathrm{g} \mathrm{g}^{-1}$ soil day ${ }^{-1}$; Kang et al. 2003, Eberling and Ladegaard-Pedersen 2005, Yang et al. 2007).

Seasonal trends in biologically active fractions of soil organic matter. According to our results, rainfall seasonality in a drier region leads to a very high increase in the biologically active fractions of soil organic matter (e.g., soil microbial biomass carbon concentrations and basal soil respiration levels) during the dry season, but does not have effects in a region where water is available. The seasonal pattern observed in the dry region may reflect accumulation of soil microbial biomass and labile soil organic matter during the rainless period. Such accumulations suggest a decrease of microbial predation and microbial soil organic matter mineralization by lack of soil moisture, frequently a limiting factor to microbial activity (Paul and Clark 1996). On the other hand, the accumulation of soil microbial biomass carbon during the dry season may be a nutrient-conservation mechanism for forest ecosystems in environments with strong rainfall seasonality (Saynes et al. 2005).

Thinning effects on biologically active fractions of soil organic matter. Within our study regions, historical disturbances of low-intensity logging have resulted in shortterm changes in the total soil carbon concentration. The results of this study suggest a striking contrast in the consequences of forest thinning in an ecosystem with an annual low rainfall rate, such as the case of forests in the dry region, in comparison with an ecosystem with higher rainfall amount, as the forests of the wet region. The thinning of forests in a low-rainfall system leads to a decrease in soil total carbon concentrations after one year of forest logging, whereas in a system registering a higher rainfall level, forest logging increases the concentration of total carbon after the same period of management. The differences between regions reflect the application of fire following logging in the dry region resulting in substantial loss of key elements such as carbon. In contrast, in the wet region after logging forest litter may be integrated to soil as a carbon and nutrient input. Studies in other temperate forests (Sathaye et al. 2001, Carter et al. 2002) have also reported an increase in the concentration of total carbon following forest thinning (i.e., short-term changes in soil carbon).

The estimated total carbon pools in the upper $5 \mathrm{~cm}$ soil depth in both regions, calculated from tables 1 and 2, indicate that these pools consistently decreased after one year of forest thinning by $24 \%$ in the dry region (from $4.7 \mathrm{~kg}$ $\mathrm{m}^{-2}$ in the old-growth forest to $3.6 \mathrm{~kg} \mathrm{~m}^{-2}$ in FL-1), and $13 \%$ in the wet region (from $4.7 \mathrm{~kg} \mathrm{~m}^{-2}$ to $4.1 \mathrm{~kg} \mathrm{~m}^{-2}$, for the old-growth forest and FL-1, respectively). In the dry region, thinning may not affect the soil microbial biomass carbon pools, calculated from tables 1 and 2, (soil microbial biomass carbon increased by only $8 \%$, from $46 \mathrm{~g} \mathrm{~m}^{-2}$ 
in the old-growth forest to $49 \mathrm{~g} \mathrm{~m}^{-2}$ in FL-1) as it would be expected. However, in the wet region soil microbial biomass carbon pools in FL- 1 decreased with respect to oldgrowth forest soils (by $\sim 50 \%$, from 63 to $33 \mathrm{~g} \mathrm{~m}^{-2}$ for the old-growth forest and FL-1, respectively), suggesting that the effect of thinning is much greater than that observed for total carbon.

The contrast in the consequences of forest thinning detected for soil microbial biomass carbon in both regions is observed also in the results of the ratios of the soil organic matter. First, as a consequence of the observed changes in soil total carbon concentration, basal soil respiration levels decrease in FL-1 of the dry region, and as expected increase in stands of the wet region after one year of logging. Accordingly, the thinning of forests in a drier region led to an increase in the ratios soil microbial biomass carbon: total carbon and basal soil respiration:total carbon one year after management, but did not have effects (as in the case of basal soil respiration:total carbon ratio) in a wet region, or the effects are opposite to those observed in the dry region (as in the case of the soil microbial biomass carbon: total carbon ratio). Thus, the present study also suggests that the response of the soil organic matter active fraction to thinning depends on the rainfall amount received by the region, which is a control of microbial biomass growth and activity.

Interestingly, there is a lack of a concomitant change in the soil carbon status in FL-20 relative to old-growth forest soils. Although we observed a clear effect of management on soil carbon one year after thinning in both regions (i.e., dry and wet regions), the effect of forest thinning on soils 20 years after management was unclear and not significant; thinning may only affect the basal soil respiration in the dry region. Thus, our results show that despite the inter-regional variation in soil carbon, environmentally controlled, the system returns to the original soil carbon status and dynamics.

\section{CONCLUSIONS}

We investigated the microbial biomass dynamics in the forests of Ixtlán de Juárez because it is one of the most labile components of the biologically active soil organic matter and has a direct effect on soil fertility, and thus plays a critical role in the recovery of soil carbon following thinning. On the other hand, the basal soil respiration is an appropriate indicator of the lability of this soil organic matter. This study provided an understanding of the ecosystem-level response to natural and human-induced environmental changes in these forests.

Microbial biomass and basal respiration in the soils have substantially different dynamics in relation to regional and seasonal scales. Our study suggests that water may act as an important control on soil carbon dynamics following forest management. The levels and dynamics of the biologically active fractions of soil organic matter may be recovered after 20 years of forest management, despite environmental differences between drier and wetter periods. Thus, the importance of regional environmental variations, such as precipitation, may exert control over ecosystem trends in a short-time after forest thinning.

In addition to these short- and "long-term" scenarios, our study on the consequences of the forest management in soils of Ixtlán de Juárez, allows us to conclude that the effects on these ecosystems will vary, depending on the specific characteristics of the region's precipitation levels. Given the potential for carbon cycling management subsequent to the impact of land use on temperate forests, the topic addressed in the present study may lead to further research.

\section{ACKNOWLEDGEMENTS}

We thank to E. Solís, R. Romualdo and I. Cárdenas for their valuable assistance in the field; also we appreciate E. Solís for the support given in the laboratory. We are also grateful to three anonymous referees for valuable comments on the submitted manuscript. J. Campo was partially supported by sabbatical fellowships from the Consejo Nacional de Ciencia y Tecnología (138403) and the Dirección General de Apoyo al Personal Académico -Universidad Nacional Autónoma de México. This study was funded by Universidad Nacional Autónoma de México (PAPIIT 208902).

\section{REFERENCES}

Anderson JPE. 1982. Soil respiration. In Page AL, RM Miller, DR Kenny eds. Methods of Soil Analysis: Chemical and Microbiological Properties, Part II. $2^{\text {nd }}$ ed. Madison, USA. American Society of Agronomy. p. 831-871.

Bond-Lamberty B, A Thomson. 2010. A global database of soil respiration data. Biogeosciences 7: 1915-1926.

Bray D, L Merino, D Barry. 2007. El Manejo Comunitario en Sentido Estricto: Las Empresas Forestales Comunitarias de México In Bray D, L Merino, D Barry eds. Los Bosques Comunitarios de México. Manejo Sustentable de Paisajes Forestales. Mexico City, Mexico. Secretaría del Medio Ambiente y Recursos Naturales, Instituto Nacional de Ecología, Consejo Civil Mexicano para la Silvicultura Sostenible. p. 21-50.

Carter MC, TJ Dean, M Zhou, MG Messina, Z Wang. 2002. Short-term changes in soil $\mathrm{C}, \mathrm{N}$, and biota following harvesting and regeneration of lobolly pine (Pinus taeda L). Forest Ecology and Management 164: 67-88.

Challenger A, J Soberón. 2008. Los ecosistemas terrestres. In Sarukhán J ed. Capital natural de México, vol. I: Conocimiento actual de la biodiversidad. Mexico City, Mexico. Comisión Nacional para el Conocimiento y Uso de la Biodiversidad. p. 87-108.

Chapela F. 2007. El Manejo Forestal Comunitario Indígena en la Sierra de Juárez, Oaxaca. In Bray D, L Merino, D Barry eds. Los Bosques Comunitarios de México. Manejo Sustentable de Paisajes Forestales. Mexico City, Mexico. Secretaría del 
Medio Ambiente y Recursos Naturales, Instituto Nacional de Ecología, Consejo Civil Mexicano para la Silvicultura Sostenible. p. 123-145.

CONABIO (Comisión Nacional para el Conocimiento y Uso de la Biodiversidad, MX). 2000. Estrategia Nacional sobre Biodiversidad de México. Mexico City, Mexico. Comisión Nacional para el Conocimiento y Uso de la Biodiversidad. $248 \mathrm{p}$.

Elberling B, P Ladegaard-Pedersen. 2005. Subsurface $\mathrm{CO}_{2}$ dynamics in temperate beech and spruce forest stands. Biogeochemistry 75: 479-506.

FAO (Food and Agriculture Organization of the United Nations). 2010. Global forest resources assessment 2010. Consulted October 7 2010. Available in www.fao.org

Finer L, H Mannerkosli, S Piirainen, M Starr. 2003. Carbon and nitrogen pools in an old-growth, Norway spruce mixed forest in eastern Finland and changes associated with clearcutting. Forest Ecology and Management 174: 51-63.

Franzluebbers AJ, RL Haney, CW Honeycutt, MA Arshad, HH Schomberg, FM Hons. 2001. Climatic influences on active fractions of soil organic matter. Soil Biology and Biochemistry 33: 1103-1111.

Fredeen AL, CH Bois, DT Janzen, PT Sanborn. 2005. Comparison of coniferous forest carbon stocks between old-growth and young second-growth forests on two soil types in central British Columbia, Canada. Canadian Journal of Forest Research 35: 1411-1421.

Huston MA, S Wolverton. 2009. The global distribution of the net primary production: resolving the paradox. Ecology 79: 343-377.

Johnson DW, JD Knoepp, WT Swank, J Shan, LA Morris, DH Van Lear, PR Kapeluck. 2002. Effects of forest management on soil carbon: results of some long-term resampling studies. Environmental Pollution 116: S201-S208.

Kang S, S Doh, D Lee, VL Jin, JS Kimballs. 2003. Topographic and climatic controls on soil respiration in six temperate mixed-hardwood forest slopes, Korea. Global Change Biology 9: 1427-1437.

Le Quéré C, MR Raupach, JG Canadell, G Marland, L Bopp, P Ciais, TJ Conway, SC Doney, RA Feely, P Foster, R Friedlingstein, K Gurney, RA Houghton, JI House, C Huntingford, PE Levy, MR Lomas, J Majkut, N Metzl, JP Ometto, GP Peters, IC Prentice, JT Randerson, SW Running, JL Sarmiento, U Schuster, S Sitch, T Takahashi, N Viovy, GR van der Werf, FI Woodward. 2009. Trends in the sources and sinks of carbon dioxide. Nature Geoscience 2: 831-836.

Li Q, HL Allen, AG Wollum. 2004. Microbial biomass and bacterial functional diversity in forest soils: effects of organic matter removal, compaction, and vegetation control. Soil Biology and Biochemistry 36: 571-579.
Paul EA, FE Clark. 1996. Soil Microbiology and Biochemistry. San Diego, USA. Academic Press. 340 p.

Rzedowski J.1991. Diversidad y orígenes de la flora fanerogámica de México. Acta Botánica Mexicana 14: 3-21.

Sathaye JA, WR Makundi, R Andrasko, R Boer, NH Ravindranath, P Sudha, S Rao, R Lasco, F Pulhin, O Masera, A Ceron, J Ordoñez, X Deying, X Zhang, S Zuomim. 2001. Carbon mitigation potential and costs of forestry options in Brazil, China, India, Indonesia, Mexico, The Philippines and Tanzania. Mitigation and Adaptation Strategies to Global Change 6: 185-211.

Saynes V, C Hidalgo, JD Etchevers, JE Campo. 2005. Soil C and $\mathrm{N}$ dynamics in primary and secondary seasonally dry tropical forests in Mexico. Applied Soil Ecology 29: 282-289.

Schilling EB, BG Lockaby, R Rummer. 1999. Belowground nutrient dynamics following three harvest intensities on the Pearl River Floodplain, Mississippi. Soil Science Society of American Journal 63: 1856-1868.

Scott NA, DY Hollinger, CA Rodríguez, H Hughes, JT Lee, EA Davidson, DB Dail, P Malerba. 2004. Changes in carbon storage and net carbon exchange one year after an initial shelter wood harvest at Howland Forest, ME. Environmental Management 33: S9-S22.

Siry JP, FC Cubbage, MR Ahmed. 2005. Sustainable forest management: global trends and opportunities. Forest Policy and Economy 7: 551-561.

Smith DM, BC Larson, MJ Kelty, PMS Ashton. 1997. The Practice of Silviculture. Applied Forest Ecology. $9^{\text {th }}$ ed. New York, USA. John Wiley. 537 p.

Striegl RG, KP Wickland. 2001. Effects of a clear-cut harvest on soil respiration in a jack pine-lichen woodland. Canadian Journal of Forest Research 28: 534-539.

Sullivan BW, TE Kolb, SC Hart, JP Kaye, S Dore, M MontesHelu. 2008. Thinning reduces soil carbon dioxide but not methane flux from southwestern USA ponderosa pine forest. Forest Ecology and Management 255: 4047-4055.

Toland DE, DR Zak. 1994. Seasonal patterns of soil respiration in intact and clear-cut northern hardwood forests. Canadian Journal of Forest Research 24: 1711-1716.

Torres-Rojo JM. 2004. Estudio de tendencias y perspectivas del sector forestal en América Latina al año 2020. Documento de Trabajo. Consulted October 7 2010. Available in www. fao.org.

Vance ED, PC Brookes, DS Jenkinson. 1987. An extraction method for measuring soil microbial biomass. Soil Biology and Biochemistry 19: 703-707.

Yang L, J Pan, Y Shao, JM Chen, WM Ju, X Shi, S Yuan. 2007. Soil organic carbon decomposition and carbon pools in temperate and sub-tropical forests in China. Journal of Environmental Management 85: 690-695. 
